\title{
Re-envisioning "Woman": Medea as Heroine in Versions by Brendan Kennelly and Marina Carr
}

\section{Karen O'Brien}

\section{Q OpenEdition \\ 1 Journals}

\section{Electronic version}

URL: http://journals.openedition.org/etudesirlandaises/3051

DOI: 10.4000/etudesirlandaises.3051

ISSN: 2259-8863

\section{Publisher}

Presses universitaires de Rennes

\section{Printed version}

Date of publication: 30 June 2012

ISSN: 0183-973X

\section{Electronic reference}

Karen O'Brien, « Re-envisioning "Woman": Medea as Heroine in Versions by Brendan Kennelly and Marina Carr », Études irlandaises [Online], 37-1 | 2012, Online since 30 June 2014, connection on 20 April 2019. URL : http://journals.openedition.org/etudesirlandaises/3051 ; DOI : 10.4000/ etudesirlandaises.3051 


\title{
Re-envisioning "Woman": Medea as Heroine in Versions by Brendan Kennelly and Marina Carr
}

\author{
Karen O’Brien, David G. Frey Fellow \\ University of North Carolina
}

Abstract

Brendan Kennelly's Medea and Marina Carr's By the Bog of Cats are particularly striking versions of Euripides' Medea for their representation of Medeas rage in light of sociopolitical realities within Ireland. Both versions conflate the general Irish political situation with the broader issue of "woman," paying homage to struggles encountered by contemporary women. Significantly, these revisions of Medea ultimately offer different models of resistance to gendered injustice and similarly reflect on transformative potential in broader dimensions of human life.

Keywords: Medea, Greek tragedy, Marina Carr, Brendan Kennelly, gender, drama, theatre.

\section{Résumé}

Medea de Brendan Kennelly et By the Bog of Cats de Marina Carr sont deux réécritures de la Médée d'Euripide qui nous frappent par leur représentation de la rage des femmes devant la réalité socio-politique irlandaise. En rendant hommage aux luttes quotidiennes des femmes d'aujourd'hui, ces pièces abordent de grandes questions sur l'identité féminine tout en explorant la situation politique irlandaise à plus large échelle. À travers leurs adaptations différentes du personnage et de l'histoire de Médée, les pièces proposent de nouvelles formes de résistance à l'inégalité sexuelle et nous mènent à une réflexion sur les possibilités de transformer la vie humaine.

Mots clé : Médée, tragédie grecque, Marina Carr, Brendan Kennelly, genre, théâtre.

\section{圈 Re-envisioning "Woman": Medea as Heroine in Versions by Brendan Kennelly and Marina Carr}

Irish writers have an enduring fascination with Greek tragedy. As Marianne McDonald informs us: "In the twentieth century, there were written close to fifty Irish versions and translations of Greek tragedy in English and close to fifty more in Irish ${ }^{1}$." While paying homage to the ancient Greeks, modern adaptations of

1. Marianne McDonald, "Rebel Women: Brendan Kennelly's Versions of Irish Tragedy”, New Hibernia Review, 9 , 3, Autumn 2005, p. 123. 
Greek tragedy in Ireland often have been politically motivated to reflect specific concerns at critical times, recalling Ireland's long history of cultural conflict, political division, and civil unrest. Two adaptations of Medea - Brendan Kennelly's Medea and Marina Carr's By the Bog of Cats - reflect not only on the general Irish political situation but also, significantly, on the often overlooked intimate struggles of the position of "woman" as a broader humanistic enquiry.

In these plays, first presented in Dublin a decade apart in 1988 and 1998 respectively, the conflation of the political and the personal brings attention to women's position and often disregarded social realities. Kennelly, on the one hand, relates Medea's rage to her triumphant vengeance as a political metaphor of the Irish situation in the North. In Kennelly's version, Medea's triumph supersedes her rage. On a more personal level, however, Medea reflects the intimate knowledge Kennelly gained from women who were deeply and profoundly suffering from betrayal and oppression. His personal experience with women's suffering from injustices propelled in response the writing of Medea, a process that assisted his own private transformation through addiction recovery. Carr, on the other hand, at first appears less celebratory of her Medea figure, renamed Hester, who commits suicide by the play's end.

However, Hester's sense of justice and the poetic mode of her death allow the play to offer a more thorough critique of women's subjection to men and enact protest to effect agency and transformation.

With one Medea figure triumphant and the other dying, these revisions of Medea ultimately offer different models of resistance to gendered injustice and alternate strategies to depict transformative potential. On the surface these adaptations gain significance from their specificity of context and setting in place and time, but they ultimately offer broader social relevance, not in terms of the more universal confrontation of institutional authority but for each tragedy's quest for human transformational possibility and in varying but very personal ways.

This wider implication would suggest that specificity of time, place, and political circumstance do not necessarily narrow or limit the play's overall relevance. José Lanters, in an article on the debate about globalization and Irish drama, states: "In spite of entrenched attitudes on the part of audiences and critics, it is possible to see a gradual move away from insular themes and positions in Irish drama over the past few decades ${ }^{2}$." Lanters points to a possible shift occurring in post-September 2001 adaptations of Greek tragedy in which at least one version seeks to be less insular and allegorical in terms of its politics and Irishness (38). The apparent trend away from specificity, even if transnational in its approach,

2. José Lanters, “'Cobwebs on Your Walls: The State of the Debate about Globalisation and Irish Drama”, Global Ireland, eds. Ondřej Pilný and Clare Wallace, Prague, Litteraria Pragensia, 2005, p. 37. 
however, as Lanters suggests, does not necessarily make such plays more "global". She states: "It is not just that [truly great plays] are 'universal' in a broadly humanistic way, but that they gain relevance in new social or political circumstances without having to have that relevance emphatically imposed on them ${ }^{3}$." Whether the play is "universal" or even if relevance is imposed, specificity of place and time is determined through the particularized context of each production's or reader's reception.

At this time of continued production of adaptations of Greek tragedy in Ireland, it would seem also important to consider specificity and universality of previous adaptations from an inverted perspective, not only for their imposed relevance but also for their broader humanistic inquiry. Kennelly's and Carr's adaptations depict a particular moment in a way that remembers Ireland's long, tragic history, but the versions, additionally, transcend geographical and temporal limits to engage with profound feelings of deep loss and human suffering, opening a path to examine the affective potential to touch individual human lives in their own particularized contexts on pages and stages across the globe.

\section{Heroines of Justice}

The most frequently produced adaptations of Greek tragedy in Dublin have been those based on the myths of Oedipus, Antigone, and Medea. Sophocles' Antigone and Euripides' Medea were given preference in the last two decades of the century. Antigone was a significant theatrical force in Ireland in the mid1980s for confronting civil injustices. Three versions were written by Irish poets Tom Paulin, Brendan Kennelly, and Aidan Carl Mathews in 1984, and Athol Fugard's adaptation of Antigone, The Island, was presented at the Gate Theatre in 1986. Each of these modern Antigones responded, in its own way, to the efforts to advance human rights and to settle the political situation, particularly conflict and violence in the North of Ireland. When Seamus Heaney's version of Antigone, entitled Burial at Thebes: A Version of Sophocles' Antigone, was released in 2004, Thomas Sutcliffe wrote: "Antigone itself could probably be said to have acquired Irish citizenship by now, given the number of pointed adaptations of the play that Irish writers have produced ${ }^{4}$." If the 1980 s were the decade when Antigone became an Irish citizen, however, the 1990s may be said to have conferred the same privilege on another, very different woman: the Medea.

3. Ibid., p. 42.

4. Thomas Sutcliffe, "Everyday Clichés Come under Fire", The Independent-London, 23 April, 2004, p. 5. 
Four translations and adaptations of Medea received critical attention in Dublin from 1989 to 2000. Three of these versions were first produced in two major theatres in Dublin: the Abbey Theatre and the Gate Theatre. Both theatres have frequently staged Greek adaptations since their inception in 1904 and 1928 respectively. In 1989 the Gate Theatre presented Brendan Kennelly's Medea after it was staged at the Dublin Theatre Festival the previous year. In 1998 the Abbey Theatre staged a loose adaptation of Medea by Marina Carr, entitled By the Bog of Cats In 1991 Irish poet Desmond Egan published a straight translation of Medea that has not been professionally staged to date. On Egan's translation, Brian Arkins states that "such adherence to Euripides forces us to interrogate the meaning of the Greek text $[\ldots]$ without recourse to any modern material". This could not be said of many other Irish Medeas, which are very much in dialogue with "modern material". In 2000 another version of the Medea - written by Kenneth McLeish and Frederick Raphael and starring Irish actress Fiona Shaw was first presented at the Abbey Theatre before achieving international acclaim. This extraordinary proliferation of new Medeas suggests that the well-known mythic lineaments of this classical tragedy provided Irish playwrights at this particular moment with a way to articulate contemporary concerns. While Antigone brought to the stage debates about the political situation and national identity, Kennelly's and Carr's re-envisionings of Medea are significant not only for their sociopolitical perspective but also for their additional exploration of the position of "woman" in society more broadly. In Medea, the general Euripidean themes of exile and abandonment remain powerful, but the contemporary Irish versions of Medea resonate in particular with gender issues concerning motherhood and familial relationships. Kennelly's and Carr's adaptations warrant a closer look for their response to gendered injustice. They similarly highlight unfair treatment of women through engagement with more personal dimensions of human experience but attempt to disrupt inequalities in contrasting ways.

\section{Kennelly's Medea Figure: Terror and Triumph}

Kennelly sets his version in Corinth but connects his Medea to the broader oppression of colonialism in Ireland. McDonald argues: "It is not difficult to align this [Kennelly's] Medea with Irish Republicans, raised as Catholics, who will stop at nothing to secure what they see is just. In this case, Jason resembles England, exploiting Medea for what he can get from her ${ }^{6}$." Kennelly makes powerful references to bombs, recalling England's colonization of Ireland as

5. Brian Arkins, Irish Appropriation of Greek Tragedy, Dublin, Carysfort Press, 2010, p. 77.

6. Marianne McDonald, op. cit., p. 130 
well as the effect of fervent nationalism 7 . Jason suggests that Medea pray for common sense, specifically sense enough to view his urge for powerful royal connection as "useful opportunity" rather than to perceive the betrayal as "shameful ${ }^{8 ”}$. Medea counters:

Prayer is not

a way of coping with fools.

Prayer is for dealing

with the injustice caused by fools,

rhetorical idiots

and blind, ambitious

power-hungry cretins.

Prayer, my plausible friend, is

anger at what is, and a longing

for what should be.

Prayer is a bomb at the door of your house?

The words "prayer" and "bomb" connect religious prayer to national violence. Through his use of poetic language, Kennelly evokes imagery of the Troubles and then connects this national, public memory with the issue of the women's position, particularly as it is embodied in Medea's private rage, sense of intimate betrayal, and desire for marital and sexual justice. Bomb imagery further links the public memory and private rage as the Messenger describes the carnage of the death of King Creon and his daughter upon receiving Medea's poisoned gifts:

The house became a house of chaos.

Then the Princess, lying there, eyes closed, groaned in agony, began to revive $[\ldots]$

Her body became a flame, [...]

Shrivelled and contorted by the agony of fire

she fell on the floor, and only her father

was able to recognise her, so charred

and melted her beautiful features.

Nobody could tell where her eyes were,

nobody discern the least sign of the beauty of her face.

She was a melting, ugly, burning thing.

The blood, mingling with fire, fell

in blazing drops from her head,

7. See Marianne McDonald, “'A Bomb at the Door': Kennelly's Medea, 1992”, Eire-Ireland, 28, 2, 1993, p. 129-

137, particularly p. 134. Also see McDonald, "Rebel Women”, op. cit., p. 132.

8. Brendan Kennelly, Medea: A New Version, Newcastle upon Tyne, Bloodaxe Books, 1991, p. 42.

9. Ibid., p. 42. 
the flawless white flesh melted from her bones,

as the unseen poison consumed her, bit by bit [...]

the black ruin that was once a fair princess ${ }^{10}$.

The graphic language throughout the passage evokes the imagery one would expect in the aftermath of a bomb explosion, and Medea's sense of justice clearly resonates with Ireland's political situation. The scenes also correlate with nationalist ideology and acts of terrorism in Ireland. Although she aims to shield herself and persevere as a woman on her own terms, Medea's extreme acts function to complicate our perception of woman. McDonald writes, "Suffering in Euripides leads to arming $[\ldots]$ it teaches the victim to imitate the victimizer ${ }^{11}$ ". As prey turned predator, Medea destabilizes and politicizes conventional gender binaries. McDonald calls Medea "every philandering husband's nightmare ${ }^{12}$ ". However, Medea's strategies of militant resistance link her to classic discussions about activist tactics and leave us to consider how best to expose injustice.

\section{Kennelly's Personal Resonance}

Kennelly's exploration of the nature of Medea's rage resonates with his life in a very personal way. Kennelly candidly discusses his identification with Medea's fury in the preface to his published play text. While battling alcoholism in 1986 he sought recovery at St. Patrick's hospital in Dublin. During his stay, he attended group meetings where he experienced the rage of betrayed women through their stories of endured abuse and deception. In the preface to his Medea, Kennelly writes:

I was trying to recover from prolonged alcoholism and I found myself listening, [...] especially to women. The women I listened to ranged in age from about seventeen to about seventy. Many of them had one thing in common. Rage. Rage mainly against men, Irishmen like myself. [...] I became aware of the fact that a major reason for their rage was because they were more conscious than the men they'd lived with, or left, or been jilted or betrayed or beaten up by. [...] [T]heir words were often savage and pitiless and precise. Some of them seemed to me to be unutterably hurt. [...] The rage of these women was the rage of people who'd been used and abused over the years by men who quite often didn't even visit them in hospital. [...] This was the rage that I tried to present in Medea ${ }^{13}$. 
How does a man effectively translate Medea to meditate on women's rage against men? As a man, Kennelly offers the "consciousness" that the indignant women found absent in men. In this way, his version serves as an apology for "Irishmen like myself". Kennelly's exploration of women's rage against men acknowledges the wrongs and wounds suffered. The structure of the play itself reflects his journey to sobriety. A shift in language occurs between acts I and II, as discussed by Kelly Younger in his book, and the language serves as a metaphor for Kennelly's very personal struggle to recovery ${ }^{14}$. In Act I, Kennelly uses vivid, unforgiving words for Medea to confront Jason and his betrayal:

Stink of the grave, rot of a corpse's flesh,

slime of the putrid world,

unburied carcass of a dog in the street,

black-yellow greeny-spit of a drunk midnight -

these are my words for you ${ }^{15}$.

John McDonagh points to "Kennelly's penchant for the venomous mot juste" in this scene, comparing it to a translation by Philip Vellacott in which Medea calls Jason a mere "filthy coward ${ }^{16 "}$ ". The choral ode in act II, in contrast, presents moderate to sober language: "Love knows no limits [...] My truest home is moderation, it's/like living in a house of courage." The emphasis on moderation, limits, and courage corresponds with the philosophy of the ancient Greeks and suggests that this principle of restraint is necessary to Irish society as well. In his recent book release, Arkins states, "This archetypal role that Medea plays links up both with Kennelly's own personal life and with wider concerns about society in Ireland ${ }^{17}$. Kennelly's experience of recovery brings an important contemporary Irish resonance to his Medea, but the most significant aspect is the play's conflation of the political and personal to make the presence of "woman" more profound in a broader context.

More than responding to Irish political issues, Kennelly demonstrates the contemporary importance of his version of Medea as a warning to spectators and readers that women are not to be disregarded. McDonald asserts, "Brendan Kennelly transformed the main rebel women he put in his plays into heroines, and specifically Irish heroines ${ }^{18}$ ". Kennelly, additionally, presents the broader "human

14. Kelly Younger, Irish Adaptations of Greek Tragedies: Dionysus in Ireland, Lewiston, The Edwin Mellen Press, 2001, p. 140-141. See also Marianne McDonald, op. cit., "Rebel Women”, p. 123-136.

15. Brendan Kennelly, op. cit., p. 36.

16. John McDonagh, “'Is Medea's Crime Medea's Glory?' Euripides in Dublin”, Amid Our Troubles: Irish Versions of Greek Tragedy, eds. Marianne McDonald and J. Michael Walton, London, Methuen, 2002, p. 228.

17. Brian Arkins, op. cit., p. 79.

18. Marianne McDonald, "Rebel Woman", op. cit., p. 125. 
passion ${ }^{19}$ " of his Irish heroine through her powerful force unleashed with insult and injury. In his preface, Kennelly writes:

The Medea I tried to imagine was a modern woman, also suffering a terrible pain - the pain of consciousness of betrayal by a yuppified Jason [...]. Medea, as I imagined her, plans to educate Jason in the consciousness of horror; she destroys his world but leaves him intact. [....] Medea, as I see her, inflicts on Jason the ultimate cruelty; she sentences him to life ${ }^{20}$.

In addition to conveying the enormity of betrayal through Medea's rage, Kennelly seeks for Medea a quality of the extraordinary. She is able to alter her position and transform her life predicament. Kennelly illustrates Medea's exceptional resilience: "Euripides presents her as an abandoned, betrayed woman bent on revenge; he also brilliantly suggests the twisted consequences of that revenge. Medea is transfigured into an almost superhuman destroyer by her sense of wrong $^{21}$ ". Medea, numinously and willfully, relegates Jason from his newly-found royal status to an inglorious inferior. She transcends being a scorned woman to reach wondrous glory. Kennelly's entitles Medea to this superhuman quality in extending Euripides' ending to ask: "And yet I wonder, and will always wonder-/ Is Medea's crime Medea's glory 22 ?" We already know the answer because Medea is victorious. McDonald analyzes it concisely: "In Euripides' play, Medea’s victory was ambiguous; in Kennelly's play, she wins ${ }^{23}$." Although the triumphant vengeance of Medea depicted in Kennelly's added lines does not translate the uncertain ending of Euripides' original, it depicts Kennelly's personal quest for transformational power through recovery and his experience of women's oppression.

Kennelly's Medea works to redefine the position of "woman" for both Irish women and women more generally as well as to reflect broadly on the promise of human transformation. Kennelly gives Medea strength and glory. She chooses to become an agent to resist gendered injustice. She refuses to self-destruct in the face of betrayal, loss, and exile. Medea, alternately, produces consequences for Jason's violation and drive for power by strategically devising a plot of vengeance. Jason's new royal refuge becomes a quasi-bomb site. The result is reported by the Messenger: "Side by side they lay,/father and daughter,/King and Princess, unfleshed,/dead. Burnt bones./[...] Two burnt corpses on a royal floor ${ }^{24}$." Without justifying the violent murder of King Creon and the Princess or her subsequent acts

19. Ibid., p. 125.

20. Brendan Kennelly, op. cit., p. 8.

21. Ibid., p. 8.

22. Ibid., p. 75.

23. Marianne McDonald, “'A Bomb”, op. cit., p. 136.

24. Brendan Kennelly, op. cit., p. 70. 
of filicide, Kennelly's version evokes empathy with Medea's decision to become an active agent rather than a passive victim, propelling agency relevant to Irish debates about the position of women in society.

Women have suffered gendered injustice in both private and public spheres, particularly in regards to marriage and motherhood. For women in Ireland, marriage ultimately served as an oppressive, unjust institution of "social exclusion". John McDonagh asserts: "Marriage proves to be the 'revelation', a state of free-fall as the man exhibits 'a sudden loss of interest in her body', usually leading to the social exclusion of the woman ${ }^{25}$." Although the Irish Constitution of 1937 aimed to protect the family structure by not obliging the mother to work outside the home, its repetitious emphasis on the woman's place in "the home," as articulated in section two of article 41, politicizes the maternal, promoting woman as mother to the exclusion of other roles. In her examination of article 41, Melissa Sihra states that "'woman' is explicitly defined by the role of 'mother', and the two terms remain interchangeable ${ }^{26 "}$. Kennelly's Medea unsettles this interchangeability without lessening the social value of either role. Medea finds her womanhood chiefly in terror and triumph, and she makes the difficult decision to sacrifice motherhood, as seen when she brutally murders her children.

J. Michael Walton contends: "Knowing at first hand, and sympathizing with, the struggles of women in Ireland, Kennelly seems to find a kind of justice in Medea's destruction of her children that places in the frame a whole stratum of Irish social history ${ }^{27}$ " (29). Despite the fight for equal rights throughout the twentieth century, Irish women often sacrificed their ambitions for the greater good of the country only to find themselves silenced and devalued. Arkins states: "Kennelly's Medea should be read against the reality of marital breakdown in Ireland, and the debates about divorce that took place in the 1980s and 90s (it became legal in 1997) 28 ." Arkins links Kennelly's personal experience of divorce to his identification with betrayed women who provided him with "female knowledge" for the

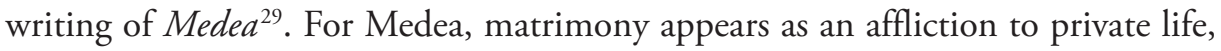
but she outmaneuvers Jason to assert herself in the male-identified public sphere. The conflation of Irish politics and the position of woman in Kennelly's Medea functions to resist gendered injustice and ultimately to enact a broader human transformation by the play's end.

25. John McDonagh, op. cit., p. 215.

26. Melissa Sihra, "Introduction: Figures at the Window", Women in Irish Drama: A Century of Authorship and Representation, ed. Melissa Sihra, New York, Palgrave, 2007, p. 2.

27. J. Michael Walton, "Hit or Myth: The Greeks and Irish Drama", Amid Our Troubles: Irish Versions of Greek Tragedy, eds. Marianne McDonald and J. Michael Walton, London, Methuen, 2002, p. 29.

28. Brian Arkins, op. cit., p. 79.

29. Ibid., p. 79. 


\section{圈 Carr's Medea Figure: Suicide as Literary Protest}

Carr's By the Bog of Cats is freely adapted, unlike Kennelly's version, which more closely translates Euripides' original ${ }^{30}$. First presented at the Abbey Theatre, Carr's version alters the locale from Corinth to an icy bog of the Irish Midlands with its distinct dialect. Although it is a loose adaptation, By the Bog of Cats retains the general plot and themes of Medea as well as the driving force of Medea's rage without sacrificing her original fusion of passion and reason. Written from a woman's perspective, Carr's version counters "traditional" Western perspectives of motherhood, marriage, familial relationships, and Catholicism to magnify the position of "woman" and provide a mode of transformation through death.

Frank McGuinness's well-known programme note from the first Abbey production tells us that Carr "knows what the Greeks know. Death is a big country. [...] I am certain in this play she writes in Greek ${ }^{31 "}$ ". The bog landscape "from which Carr writes", Sihra argues, is "where the ethereal cohabitates with the mundane, where the world of poetry and storytelling is a necessary part of the everyday ${ }^{32}$ ". This dual status of death and of landscape functions to challenge the rigidity of hierarchal structures and insular thought. The play resists such structures by symbolically presenting transformative possibility, specifically through the landscape's liminal link to the Other world and through the performance of poetic death. McDonald tells us the Irish versions of the classics often have been used as a form of protest ${ }^{33}$, and as such, Carr's utilization of such elements as death and landscape serve as a mode of literary protest.

Hester is known to be from a family of "travelers," derogatorily referred to as "tinkers." She resides in a caravan on the bogside avoiding the more permanent house, staking her undying claim to the landscape:

I was born on the Bog of Cats and on the Bog of Cats I'll end me days. I've as much right to this place as any of yees, more, for it holds me to it in ways it has never held yees. And as for me tinker blood, I'm proud of it. It gives me an edge over all of yees around her ${ }^{34} \ldots$

30. Still, Kennelly adds over 800 lines to Euripides' approximately 1400 lines in Medea.

31. Frank McGuinness, "Writing in Greek", Programme note for By the Bog of Cats (Programme Note: Abbey Theatre, 1998), The Theatre of Marina Carr: “before rules was made”, eds. Cathy Leeney and Anna McMullan, Dublin, Carysfort Press, 2003, p. 87-88.

32. Melissa Sihra, "Reflections Across Water: New Stages of Performing Carr", The Theatre of Marina Carr: "before rules was made", eds. Cathy Leeney and Anna McMullan, Dublin, Carysfort Press, 2003, p. 103.

33. Marianne McDonald, "Classics as Celtic Firebrand: Greek Tragedy, Irish Playwrights, and Colonialism”, Theatre stuff: Critical Essays on Contemporary Irish Theatre, ed. Eamonn Jordan, Dublin, Carysfort Press, 2000, p. 16.

34. Marina Carr, By the Bog of Cats..., County Meath, Gallery Books, 1998, p. 35. 
Hester demonstrates cultural difference through her hybrid form of foreigner-native. Her outsider status is similar to Euripides' Medea, who in Corinth is considered a barbarian, or non-Greek. Hester's difference is interpreted as witchery, resembling Medea's characterization as a sorcerer. Despite being marginalized as an outsider and a woman, it is her "tinker blood" that gives her "an edge" to strike back and pursue vengeance on a more elevated scale. Likewise, Medea's foreigner status enables her to deal with the oppression she suffers as a woman. Carr, like Kennelly, explores woman's subjugated position in society and the resulting nature of her fierceness. Both Medeas strike with fury at the heart of patriarchy and materialism. Hester refuses to be victimized and instead exerts force to retaliate. Her suffering and rage activate personal strength to fight for justice and honor for herself beyond the limits of morality and law in the face of oppression.

Carr utilizes death as a poetic mode to show potential for transformation where there seems to be none. At the beginning of the play, Hester encounters a dead black swan, her alter ego whom she drags along leaving in her wake a trail of blood in the snow. Mary Trotter states: "The death of the swan, frozen into the bog it was unable to fly away from, reflects Hester's own psychic entrapment within this community ${ }^{35}$." The swan foreshadows Hester's death, which looming propels Hester's defiance against a seemingly inevitable fate. Hester is greeted, additionally, by the Ghost Fancier, a supernatural Death figure who arrives mistakenly at dawn to carry her into the world of the nonliving. Ghost Fancier, unable to decipher linear time, confuses dawn for dusk and promises to return at twilight, the play's end, to escort Hester into exile through a "death dance ${ }^{36 "}$. Both the black swan and Ghost Fancier portend Hester's death, and Carr's use of foreshadowing shifts, as Trotter notes, "from the Euripidean source in a more Irish, feminine, and psychological territory ${ }^{37}$ ". This new private territory offers a symbolic space of potential transformation. Her most powerful characters are able to transverse the threshold of the living to communicate with the dead. By the Bog of Cats, however, differs from Euripides' Medea in two important ways: Hester's act of filicide; and her ultimate escape through suicide. The deaths of mother and child demonstrate brave resistance to the prescribed role of motherhood to redefine the position of "woman".

Hester's purpose for killing her daughter, Josie, is multifaceted. It is not simply an act of revenge or resistance. Hester's slaying of Josie is motivated, moreover, by her instinctive need to protect Josie in the future from the self-interested Carthages and child molesting Xaviers of the world. Carthage Kilbride, her longtime life partner, has taken everything that Hester has not already lost in life. When

35. Mary Trotter, Modern Irish Theatre, Cambridge, UK, Polity Press, 2008, p. 188.

36. Marina Carr, op. cit., p. 80.

37. Mary Trotter, op. cit., p. 188. 
Carthage threatens to take their daughter Josie, Hester replies: "I should've known ya always meant to take her too ${ }^{38}$." As a result, Hester kills Josie in a desperate attempt to hold on to something of her own. Hester's killing of Josie overall emphasizes the mother-daughter bond, whereas Medea's murder of her two sons is a subversive act to destroy the father-son bond and relegate Jason to the broken emotional state of the perceived stereotype of woman. John McDonagh states: "In Ireland in the year 2000 six children died at the hand of a suicidal parent [...] The taking of children by a suicidal parent is an occurrence that brings the often bizarre nature of parental love into sharp focus and can, in certain circumstances, be regarded as an act of ultimate love ${ }^{39}$." Hester's filicide is enacted to spare Josie the same anguish of abandonment she suffered by her own mother at the same age of seven. The "act of ultimate love" affirms motherhood while showing a performance of maternity that is wildly at variance with "traditional" ideas of acceptable motherly characteristics.

Carr's personal life interestingly demonstrates a strong dedication to both motherhood and self-actualization. She relates her private experience of childbearing and growing a family to her writing career in a meaningful way. In the introduction to her second volume of plays, she claims her works are mostly memorable for their proximity to her experience of childbearing. She states: "What I remember most about these plays was I was either pregnant, breastfeeding, or about to be pregnant ${ }^{40}$." Interweaving parental responsibility and childbearing into her brief discussion of each play, she suggests that motherhood is somehow connected to her writing ${ }^{41}$. Her own success as a writer demonstrates that family need not come to the exclusion of professional development and that motherhood does not preclude great success outside the home. Nor does it exclude political agency, as By the Bog of Cats, with its critique of capitalism, addresses injustices beyond the domestic sphere.

The literary representation of "woman" in her play works as a rejection of conservative values of the family but not of the family itself. Hester desires family life but seeks justice and redefinition of the notion of "woman". By the Bog of Cats explores the women's position through the role of mother, specifically maternal abandonment, to resist the stereotypical role of motherhood. In By the Bog of Cats, ultimately, the absence and ineffectuality of mothers work to counter "tradition". Hester has spent her life waiting for her mother, Big Josie, to return. Big Josie deserted her at the age of seven. The themes of abandonment and exile correspond to Euripides' Medea but are also frequent in Irish literature. Hester

38. Marina Carr, op. cit., p. 75.

39. John McDonagh, op. cit., p. 218.

40. Marina Carr, "Introduction", Plays Two, London, Faber and Faber, 2009, p. Ix.

41. Ibid., p. IX-X. 
and Big Josie were relegated to the periphery of society, exploited, and repressed by the likes of the wealthy farmer and landowner Xavier Cassidy, who is soon to be the new father-in-law of Carthage. Carthage's given name recalls the Greek seaport lost in battle and the surname portends Hester's final demise. Trotter states: "In many of Carr's plays mundane, materialistic individuals are juxtaposed by deeply passionate figures - usually women - in touch with a sense of history, desire, purpose, or love that can make them behave obsessively, cruelly, selfishly, and tragically. They are a far cry from the long-suffering obedient women who have inhabited so much of Irish drama ${ }^{42}$." Even Josie's grandmother, Mrs. Kilbride, cruelly taunts her granddaughter for being a Swane-Kilbride mix rather than a full-blooded Kilbride. Hester's defiance, however, redefines the position of "woman" in Irish drama and society, especially in her struggle both to gain autonomy and to abandon the logic of the oppressive social structures that generate feelings of bias, fear, and hatred to which characters like Carthage and Mrs. Kilbride have succumbed. In the end, Hester willingly chooses death for her daughter as a symbolic act of protest and love.

After slaying Josie, Hester commits suicide, which functions as an act of courage, her own escape and refuge from patriarchy. In the Other world, however, Hester intends to maintain an everlasting bond with Carthage and exact her vengeance on him through eternal haunting. Fed up with being disregarded especially by those closest to her, she warns:

Ya won't forget me now, Carthage, and when all of this is over or half remembered and ya think yàve almost forgotten me again, take a walk along the Bog of Cats and wait for a purlin' wind through your hair or a soft breath be your ear or a rustle behind ya. That'll be me and Josie ghostin' $\mathrm{ya}^{43}$.

Even though Hester and Carthage never married during their fourteen-year relationship, Hester's obsession with "ghostin"” Carthage is a response to an unrequited marital vow that transcends "until death do us part" with the promise of a never-ending union.

Still, By the Bog of Cats works to destroy and redefine symbols and structures of marriage, family, and the authority of the Church. While the plot structure of By the Bog of Cats is similar to Euripides' Medea in its story of abandonment, betrayal, and vengeance, the centrality of the wedding and marriage of the Jason figure, Carthage, ultimately works to undermine the power/authority of its structure and symbolism. Hester, like Medea, is in conflict with Carthage. Despite their broken bond, Hester and Carthage share an attachment deepened by their

42. Mary Trotter, op. cit., p. 188.

43. Marina Carr, By the Bog of Cats, op. cit., p. 80. 
complicity in the murder of Hester's brother, Joseph. The murder brought Hester additional inheritance, which was used to finance Carthage into business. The financial capital positioned him as a respectable suitor for a new life he now seeks with the prosperous Cassidy family. Medea, similarly, sacrificed her brother in Jason's interest. Carr, however, departs from Euripides' structure but continues to emphasize themes of abandonment and exile to explore the role of motherhood. Unlike Medea, Hester claims that the primary motivation for killing Joseph was his disregard for her feelings of rejection by her mother:

If ya hadn't been such an arrogant git I may have left ya alone but ya just wouldn't shut up talkin' about her as if she wasn't my mother at all. The big smug neck of ya! It was axin' to be cut. And she even called ya after her. And calls me Hester. What sourt of a name is Hester? Hester's after no wan. And she saves her own name for you - Didn't she ever tell ya about $\mathrm{me}^{44}$ ?

Joseph exacerbated Hester's sense of abandonment stemming from her mother's departure. Hester feels that she does not have a sufficient familial tie being named after "no wan". Furthering Hester's sense of exclusion, Carthage, now set to marry Caroline Cassidy, daughter of Xavier, intends to silence and exile Hester so she does not interfere in his new life.

Carr not only shows a disillusioned view of the institution of marriage but also deconstructs its symbolism and structure through Hester's resistance to physical and psychic confinement. In Euripides' original, Medea poisons King Creon and his daughter, but Hester does not kill for vengeance in the same way. In fact, Hester spares Xavier and Caroline. She instead arrives uninvited to Carthage and Caroline's wedding donning a wedding dress herself. The wedding dress is significant as there are four white dresses, complicating the notion of matrimony. Caroline, the bride, obviously wears a wedding gown, but Mrs. Kilbride also takes liberty to don a white dress, perhaps an incestuous move. Josie wears her communion dress, and perhaps that along with her desire to go on her father's honeymoon also suggests incestuous desire, more interesting in conjunction with the religious connotation of the dress. Finally, Hester presents herself in the wedding dress once purchased but never worn for her own marriage to Carthage. The white gowns represent sociocultural "tradition" yet the accumulation of them undermines the trinity of femininity, Irish identity, and the Catholic Church. After thoroughly ruining the wedding, Hester burns down Carthage's house and shed with livestock, lashing out against his materialism and her unjust treatment. The wedding dress deteriorates into ruin. The destruction of the wedding and the 
dress symbolically illustrates the substantive breakdown and fall of these social structures of "tradition".

Carr, additionally, reflects on the authority of the Church as ineffectual. The eccentric Father Willow is more interested in flirting with the unholy Catwoman than in attending to his congregation members. While these occasional references may suggest inclusiveness of spiritual belief or may serve as residual belief to reflect partial or abandoned faith, overall they seem to suggest the impotency or irrelevance of religion in the contemporary moment. Karl Marx stated that religion "is the opium of the people ${ }^{45}$ ", and Carr's drama perhaps reveals openness to alternatives to the metaphorical opiate. The play works to unveil and disrupt the power of ideological opiates that function to maintain social hierarchy.

Ultimately, Hester's dance with death provides a release that fulfills her particular need for personal freedom from the constraints of social inequalities. Ghost Fancier arrives providing a supernatural intervention, a sort of deus ex machina, with heightened theatrical and poetic resonance. Simply stated, it presents rich staging potential:

They go into a death dance with the fishing knife, which ends plunged into HESTER's heart. She falls to the ground ${ }^{46}$.

Hester's efforts end tragically, but the poetic treatment of death suggests agency. McDonald confirms: "In Carr's play death is a refuge for the mother and daughter, a place where they can be free from patriarchy ${ }^{47}$." Eamonn Jordan further affirms: "Hester murders her daughter not out of some irrational impulse but with the calculation and formality that defy the accusation of hysteria or frenzy. Her own destructive agency is in evidence 48 ." In Carr's adaptation, as in Kennelly's, the conflation of sociopolitical realities and gendered injustice works to resist these authoritative social structures and provide a mode of transformation.

Although Hester's suicide may at first appear to be reinforcement rather than subversion of the maternal role, Hester's "edge" demonstrates her defiance, in particular resistance to oppression of traditional structures of motherhood and matrimony. Her suicide death at the play's end does not affirm and reestablish patriarchal order. In Carr's plays, Sihra states, "[d]eath on stage does not indicate finality, but movement; it is a poetic drive to excavate what it means to live [...] 'Death' per

45. Karl Marx, "Contribution to the Critique of Hegel's Philosophy of Law", Collected Works, eds. Karl Marx and Frederick Engels, 3, Moscow, Progress Publishers, New York, International Publishers, 1975, p. 175.

46. Marina Carr, By the Bog of Cats, op. cit., p. 80.

47. Marianne McDonald, "Classics”, op. cit., p. 22.

48. Eamonn Jordan, "Unmasking the Myths? Marina Carr's By the Bog of Cats and On Raftery's Hill', Amid Our Troubles: Irish Versions of Greek Tragedy, eds. Marianne McDonald and J. Michael Walton, London, Methuen, 2002, p. 261. 
se, can offer no resolution unless it is viewed as a symbiotic dynamic of living ${ }^{49}$ ". Carr's characters have concerns beyond motherhood and the role of the wife. Her woman characters depict the quest for a space to express themselves differently from the limits of representation in modern Irish drama. Carr expands the limits of previous gender representation through the poetic use of death and the Otherworld. By investigating women's experience outside the domestic sphere, Carr opens possibilities for women to be perceived and represented differently and to occupy new psychic and physical spaces on the stage.

\section{Mythic Transformation}

Kennelly and Carr have written versions of the Medea myth that not only show that tensions of Athenian culture are still current in Ireland but also reflect a quest to overcome oppressive forces of a broader human struggle. These revisions of Medea, however, ultimately offer different models of resistance to gendered injustice. Medea's fury resonates in personal ways for Kennelly, most significantly in how suffering activates change, seen particularly through a man's coming to consciousness about women's rage against men. Kennelly suggests that this recognition facilitated his personal journey to recovery. The rage of Carr's Medea also brings identification with Irish life. Carr takes liberties with the original to make it resonate with Irish myth and Ireland's Midland landscape of bogs. Unique to Greek tragedy, Carr brings to the forefront a woman's perspective through the emphasis on the mother-daughter relationship. In seeking alternate ways to generate movement out of cycles of gendered oppression and entrapment, Hester must take exile. It is in the realm of death that she finds refuge and freedom. Carr disturbs the power of symbols and structures of marriage, family, and the authority of the Church to resist gendered injustice and shows symbolic transformational potential in a quest for the redefinition of the position of "woman".

The re-envisioning of Greek myth in these Irish versions works to enlarge the relationship between Irish history and sociopolitical realities in the present. They also stage resistance to gendered injustice and demonstrate the transformative potential of social struggle in broader dimensions of human life.

49. Melissa Sihra, "Reflections Across Water: New Stages of Performing Carr", The Theatre of Marina Carr: "before rules was made", eds. Cathy Leeney and Anna McMullan, Dublin, Carysfort Press, 2003, p. 112. 